\title{
Enhance Nurse Managers' Legal and Ethical Aspects at Benha University Hospital
}

\author{
Salwa Mahmoud Mohamed Mostafa ${ }^{1}$, Eman Salman Taie ${ }^{2}$ and Howida Hassan El-Sayed ${ }^{3}$
}

(1)MSc Nursing 2013, (2) Professor of Nursing Administration, Faculty of Nursing, Helwan University and (3) Assistant professor of Nursing Administration, Faculty of Nursing, Benha University

\begin{abstract}
Backgrounds: Nurse managers' are facing the challenges in their daily practice such as short of staffing, workload and maintenance of high quality and encounter many legal and ethical issues surrounding these area. Law defined as a legal document setting rules governing a particular kind of activity while ethics are moral principles that govern how the person or a group will behave. Aim of the study: Was to enhance nurse managers' in the legal and ethical aspects at Benha University Hospital. Research design: A quasi-experimental design was utilized. Sample: Composed of 79 nurse managers include nursing director (1), supervisors (14), and first line manager (64). Setting: The study was conducted in all units (44) at Benha University Hospital. Tools for data collection Two tools were used; the first tool: legal and ethical aspects knowledge questionnaire sheet. The second tool: legal and ethical aspects observational checklist. Results: Majority of the studied sample had unsatisfactory knowledge level about legal and ethical aspects at preprogram, while immediate post educational program the majority of them had satisfactory knowledge level. Also, the minority of the studied sample pre educational program demonstrated complete performance about legal and ethical aspects, while post program the majority of them improved their performance. Additionally there was astatistical significant positive correlation between nurse managerg's total knowledge scores and performance scores. Conclusion: There were an improvement in level of knowledge and performance of the nurse mangers about legal and ethical aspect immediately post and follow-up implementation of educational program compared to pre-program. Recommendations: Establish an ethical and legal committee within the organization for all ethical and legal aspects in nursing practice. Further research: effect of legal and ethical nurses' knowledge on patients outcome.
\end{abstract}

Key words: Ethical aspects, Legal aspects, Nurse managers.

\section{Introduction}

Health maintenance and healthcare provision are the primary functions of the healthcare delivery systems; the system is not isolated from society and therefore impacts and is impacted by societal value and beliefs. It is also accountable for maintaining legal and ethical standard established by society to apply at with health care providers, and the healthcare consumer (El-bayome, 2017; Dagogo \& Ehior, 2019).

Healthcare providers such as the nursing and healthcare profession is faced with increasing legal and ethical challenges as a result of increased medical care, work load, and dynamic modes of communication and increased responsibilities for nursing professions. The role of professional nursing continues to expand and incorporate 
increasingly higher levels of expertise, autonomy, and accountability from both legal and ethical perspectives. This evolving role has focused new concerns for nurse managers, nurse leaders and awareness of the interaction of legal and ethical principles (Fukada, 2018; Karaca \& Durna, 2019).

Nurse managers are people who appointed to positions of authority, which enable their staff to perform their work effectively, who have responsibility for resource utilization and who are accountable for work results and what they do. It becomes apparent that the nurse managers needed to get work done through people is increasingly important for nurses to dispose their professional performance (Younis, 2017; Salah et al., 2018).

Nurse managers have a responsibility to the patients they serve by supporting an environment that promotes advocacy for health and healing of patients within their own emotional and psycho social support system. Setting the example of the professionalism, the manager leads by influence and models the behaviors that the direct care (Daly et al., 2014 \& Araby, 2018).

Nurse managers is responsible for creating effective, safe and healthy environments that support the work of the healthcare team and contribute to patient engagement and satisfaction. The role is influential in creating a professional environment and fostering a culture where interdisciplinary team members are able to contribute to optimal patient outcomes and grow professionally, with full consideration to patients' rights, believe, value and way of communication. The nurse managers should be full oriented they retain personal liability for assignment, delegation, and supervision activities (Lundy \& Jones, 2016 \& Werberg et al., 2019).

Nurse managers must know the applicable standards of care and ensure that all nursing staff of the hospital meets them. They are personal liability (it is the state of being legally responsible for something) for the reasonable exercise of assignment, delegation, and supervision activities. The failure to assign, delegate, and supervise within acceptable standard of professional nursing practice constitute malpractice (Feather \& Ebright, 2013; Hamid, 2016 \& Alrobai, 2020).

Nursing liability refers to a nurse legal responsibility for harm caused to a patient by an inappropriate nursing practice. Nurse managers is responsible for using sound judgment and making appropriate nursing decisions, they can hold liable if the nursing staff action result from manager decision and harm or injury the patient. A nurse manager is not liable if the nurse action is proved to be beyond the limits of expected professional behavior. So, nurse managers need to know certain definitions regarding area of law (Ragon, 2016 \& Demirhan et al., 2020).

Law is a socially oriented discipline and is committed to the welfare of society. Laws tell us what one can and cannot do. However, laws are not static; they move with time and with new technology as needed of society. Nursing laws are not a separate entity it draws from general laws, rules, and regulation. Certain types of laws create rights and responsibilities for nursing staffs such as statutory law, public law, criminal law, and common law (El-bayome, 2017; Singh \& Mathuray, 2018). 
Law play critical role in guiding medical practices in nursing field it differentiates the nurses responsibilities from others health professional, provide framework for establishing which nursing actions to care of patients, and assists in maintaining a standard of nursing practice. The main goals to know law to educate nurse manager regarding their responsibilities and accountabilities to patient care, staff management, units management and the complex issues involved in basic legal situation (Abo-Roman, 2019 \& Gab-Allah et al., 2020).

In the real clinical settings the nurse manager must encourage ethical practice, guide direct care staff in delivering excellent quality care, and sets professional philosophy should include the patient's rights. These rights have traditionally identified such basic elements as human dignity, integrity, safety, comfort, continuity, honesty, confidentiality, privacy, choice and informed consent (Josef, 2017;

\section{Moline-Mula \& Estrada, 2020).}

Ethics are rules that govern right conduct while ethical behavior means that a person behaves according to a code of ethics. A code of ethics is developed and accepted by members of a profession it provides a guide for what is good and bad and morally obligated, the first code of ethics was adopted by the American Nursing Association (ANA) in 1950 (Donates, 2011;

\section{Mohamed, 2017; World Health Organization [WHO], 2019).}

The ethical principle such as (beneficence, non-maleficence, accountability, fidelity, veracity, and autonomy); Beneficence that mean assumes a fundamental duty to serve the best interest of their patients by treating/ preventing disease, non-maleficence that means that duty to benefit patients is the corresponding to refrain from harm, justice that mean acting with fairness to provide care to patients regardless of race, color, creed, gender, nationality and other irrelevant properties. Veracity is to be completely truthful with patients. Autonomy, the patient has the right to reject or accept all treatments

(Habimana, 2016; American Nurses Association [ANA], 2019; Haddad \& Geiger, 2020).

\section{Significance of the Research}

Nurse Managers in every day face legal and ethical dilemmas. One of the professional competencies for nursing status that nurses in any level should integrate knowledge of ethical and legal aspects of healthcare and professional values into nursing practice. In many clinical setting the nurse manger as a member of health care team and she is the most central to all nurses, patients' family, physician, and ancillary healthcare providers. So, in that position she needs to be able to promote in legal and ethical-decision making when questions arise about the care plan (Shrestha, 2014; Mahran, 2017; Drucker, 2018). Nurse Managers who are aware of their rights and responsibilities' in legal and ethical aspects are better able to protect themselves against lawsuit or loss of professional licensure. Therefore, this study will be conducted to enhance nurse mangers' in the legal and ethical aspects at Benha University Hospital. 


\section{Aim of study:}

The present study aimed to enhance nurse managers' in the legal and ethical aspects at Benha University Hospital.

\section{Research hypothesis}

It was hypothesized that; there will be an improvement in nurse managers' knowledge, and performances regarding legal and ethical aspects in their work settings post the designated educational program.

\section{Subjects and Methods:-}

Research Design: A quasi experimental research design was used to conduct this study.

\section{Study Setting:}

The present study was conducted in all units (44) at Benha University Hospital. The total number of beds in all units were (506) beds. The hospital composed of three separated buildings; firstly, Medical Building consisted of 30 units (315 beds). Second, Surgical Building consisted of 12 unit (179 beds). Finally, Ophthalmology building includes 2 units (12 beds).

\section{Sample:}

All nurse managers who were available at the time of study. The subjects of this study sample were composed of (79) nurse managers who had at least one year of experience. This group consisted of three levels of Nurse Mangers; top-level nursing director/ matron (1), middle level supervisors /assistance director (14), and first line manager/head nurses (64) all of them participated in the study. They included those who more than one year of job experience in the current job in their work setting, and exclude those who were attended previously training program in the legal and ethical aspects in nursing.

\section{Tools of data collection:}

Data for the present study was collected through using the following two tools;

I, Legal and ethical aspects knowledge questionnaire: A structured questionnaire was developed by the researcher after review of related literature guided by (Ashour, 2006; Yousef, 2010; Wise, 2015; Al-Breiki, 2017), to assess the nurse managers' knowledge about legal and ethical aspects in their work settings. It was consisted of two parts. Part 1, personal and occupational data like (gender, age, educational level, departement, job postion, yeas of experience, working hours, and existence of legal and ethical commuittee in the hospital) and part 2, Legal and ethical aspects knowledge questionnaire. It consisted of (55) questions classified under six main categories; first (13) question related to entrance of laws, second (24) questions related to civil service law number 81 copy, (2016), third (7) question related to code of ethics, forth (6) question related to ethical principles, fifith (3) question related to patient's rights and sexth (2) question related to process in ethical dilemma.

\section{Scoring system}

The questions were scored as (1) for correct, and (zero) for incorrect or do not know. So, the total scores was (55), and the cut point was done at $70 \%=38.5$ grades. Total knowledge score was calculated as follows:

- Satisfactory score equal or more than 38.5 grades $(\geq 70 \%)$.

- Unsatisfactory score less than 38.5 grades $(<70 \%)$.

II, Legal and ethical aspects observational checklist for nurse manager: An obervational checklist developed by the researcher after review of related national and international literature 
guided by (Hariharan, 2013; Vati, 2014 ; Rich, \& butts, 2016 \&El-Byome, 2017), to evaluate nurse manager's actual performance regarding legal and ethical aspect in their wok settings as observed by the researcher. It was consists of (69) items classified under seven main category, first (8) items related to legal aspect during area of supervision, second (9) item related to legal aspect toward drug management, third (8) items related to legal aspect toward equipment management, fourth (8) items related to legal aspect toward patient documentation, fifth (13) items related to ethical aspect toward the patients, sixth (19) items related to ethical responsibilities toward staffs, and seventh (4) items related to ethical responsibilities toward unit.

\section{Scoring system}

The items were scored as (2) for done complete, (1) for done incomplete and (Zero) for not done. The total scoring system of the observational checklist was divided into two dimensions:

- $\quad$ First, the legal aspect (33 items); total score was 66 grades and the cut point was done at $75 \%=49.5$ score.

- Done complete scores equal or more than 49.5 grades $=\geq 75 \%$.

- Done incomplete scores equal (33$<49.5)$ grades $=(50 \%-<75 \%)$.

- $\quad$ Not done scores less than 33 grades $=$ $<50 \%$

- $\quad$ Second, the ethical aspect (36 items); total score (72) grades and the cut point was done at $75 \%=54$ grades.

- Done complete scores equal or more than 54 grades $=\geq 75 \%$.

- Done incomplete scores equal (36$<54)$ grades $=(50 \%-<75 \%$.

- $\quad$ Not done scores less than 36 grades $=$ $<50 \%$

variables was evaluated using Person's Correlation Coefficient. $\mathrm{P}$ values were

\section{Field work}

The field work of this study was executed in eight months. Data collection began on $1^{\text {st }}$ of September (2018) and finished on the end of april(2019). Consist of three phases assessment phase, implamentation phase, and evaluation phase.

A Pilot study was conducted to assess study tools clarity and applicability. It has also served in estimating the time needed for fulfilling the study tools. The revised questionnaires were piloted with $10 \%$ from the subject: (8) nurse managers were included to investigate the feasibility of data collection tools. Collecting pilot study data lasts for one month. The time needed to fulfill legal and ethical knowledge questionnaire ranged between (25- 35) minutes. While, for observational checklist it was ranged between (30-40) minutes. No modification was occurred in the pilot study so it was included in the main study subject.

\section{Ethical consideration:}

Oral consent obtained from study subjects after explaining the purpose, nature and methods of data collection for them. Also, the study subjects were informed that they are allowed to participate or not in the study and they have the right to withdraw from the study at any time. Confidentiality anonymity and right to withdraw from the study at any time were guaranteed.

\section{Statistical analysis:}

Data collected from the studied sample was revised and coded. Computerized data entry and statistical analysis were fulfilled using the statistical package for social sciences (SPSS) version (20). Data were presented using descriptive statistics in the form of frequencies and percentages. Chi-square test $\left(\mathrm{X}^{2}\right)$ was used for comparison between qualitative variables. Correlation between considered statistically significant when $\mathrm{P}=$ $<0.05$. 
Preparatory phase; served to develop the tools for data collection. Development of the tools was under supervisor guidance and experts' opinions were considered. The revision of study tools was done by a group of jury committee from different nursing specialties and faculty of law, department of social legislation to get their suggestions about validity and applicability of tool. The experts were asked to evaluate individual items and rate items as follows: (0) refer to disagree and (1) refer to agree. The study tools were subjected to assessment of internal consistency reliability using two methods: Alpha Chraumbach's test for internal consistency (0.889) and test-retest using personal correlation coefficient.

\section{B. Implementation phase}

According to the result of assessment phase the researcher designed nurse managers' legal and ethical educational program based on nurse managers needs and implemented it to study subjects. The trainees consisted of (79) nurse managers. In each educational program session the total numbers of trainees were (16) nurse managers except only one program trainees number were (15). Each group of trainees attended one day/ week for four weeks. Each day of training was consisted of three sessions; each session lasted for two hours. Each day of training was consisted of three sessions; each session lasted for two hours and the break time will be (30 minutes).

\section{Evalution phase}

Nurse managers legal and ethical educational program was evaluated to determine the extent to which nurse managers were changed their knowledge and actual performance related to nursing legal and ethical aspects.

\section{Results:}

Table (1): Shows that all of nurse managers $(100 \%)$ were female, Less than half of the sample $(44.3 \%)$ their age was more than 45 years old with mean age $(36.58 \pm 6.49)$, most of them (81\%) had Bachelor Degree, and work as head nurse. Also less than half (46.8\% \& 49.45) of nurse managers were working in critical care units and having years of experience ranged from $(10<20)$ respectively with mean years of experience

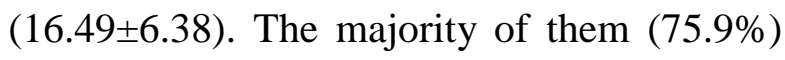
their weekly working hours were 36hours. More over most of nurse manager $(96.2 \%$ \& $91.1 \%$ ) respectively reported that there is no ethical and legal committee in their work settings.

Figure (1): Clarifies that two third $(63.3 \%)$ of the nurse managers had unsatisfactory knowledge level about legal and ethical aspects in preprogram, while immediate post program the majority ( $84.8 \%$ ) of them had satisfactory knowledge level. Moreover, the majority $(82.3 \%)$ of the study sample had satisfactory total knowledge level about legal and ethical aspects follow up implementation of the program respectively.

Table (2): Reveals that there was highly statistical significant difference between nurs managers total knowledge level about legal aspects pre and immediate post implementation of the program, while there was no-statistical significant difference between nurse managers total knowledge level about legal aspects immediate post and follow up implementation of the program.

Tables (3): Reveals that there was highly statistical significant difference between nurse managers' total knowledge level about ethical aspects in pre and immediate post implementation of the program. While, there 
was no-statistical significant difference between nurse managers' total knowledge level about ethical aspects immediate post and follow up implementation of the program.

Table (4): Shows that all items related to legal and thical knowladage such as entarance of law, civil service law, code of ethics, ethical principle with patient right, and ethical dilemma was improved post-program and follow up compered to preprogram.

Figure (2): Clearifies that one quarter $(24.1 \%)$ of nurse managers done complete performance toward legal and ethical aspects in preprogram, while majority of them $(82.3 \%, 77.2 \%)$ had done complete performance toward legal and ethical aspects in post and follow up program .

Table (5): Reveals that one qurter (25.3\%) of nurse managers done complete performance toward legal aspects in preprogram, while the majority of them $(81 \%, 77.2 \%)$ had done complete legal performance post and follow up implamentation of the program.

Table (6): Shows that majority $(82.3 \%)$ of nurse managers done complete performance toward ethical aspects in post program, while it slightly decreased to $(78.5 \%)$ in the follow up program.

Figure (3): Reveals that there was high statistical significant positive correlation between nurse managers' total legal knowledge score and total nurse managers' legal performance score post implementation of the program.

Figure (4): Shows that there was high statistical significant positive correlation between nurse managers' total ethical knowledge score and total nurse managers' ethical performance score post implementation of the program. 
Table (1): Frequency distribution of the nurse managers' personal data. $(\mathrm{No}=79)$

\begin{tabular}{|c|c|c|}
\hline Items of personal data & No & $\%$ \\
\hline \multicolumn{3}{|l|}{ Gender } \\
\hline Female & 79 & 100.0 \\
\hline \multicolumn{3}{|l|}{ Age in years } \\
\hline $25:<35$ & 23 & 29.1 \\
\hline $35:<45$ & 21 & 26.6 \\
\hline $45+$ & 35 & 44.3 \\
\hline Mean \pm SD & \multicolumn{2}{|c|}{$36.58 \pm 6.49$} \\
\hline \multicolumn{3}{|l|}{ Educational qualifications } \\
\hline Secondary nursing education & 9 & 11.4 \\
\hline Technical nursing education & 1 & 1.3 \\
\hline Bachelor of nursing & 64 & 81.0 \\
\hline Post graduate nursing education & 5 & 6.3 \\
\hline \multicolumn{3}{|l|}{ Work department } \\
\hline Nursing office & 15 & 19.0 \\
\hline Critical care units & 37 & 46.8 \\
\hline Wards & 27 & 34.2 \\
\hline \multicolumn{3}{|l|}{ Job position } \\
\hline Head nurse & 64 & 81.0 \\
\hline Supervisor & 14 & 17.7 \\
\hline Nursing director & 1 & 1.3 \\
\hline \multicolumn{3}{|l|}{ Number of weekly working hours } \\
\hline 35 hours & 9 & 11.4 \\
\hline 36 hours & 60 & 75.9 \\
\hline 42 hours & 6 & 7.6 \\
\hline 48 hours & 4 & 5.1 \\
\hline Mean \pm SD & \multicolumn{2}{|c|}{$37.12 \pm 5.23$} \\
\hline \multicolumn{3}{|l|}{ Years of experience } \\
\hline$<<5$ & 3 & 3.8 \\
\hline $5<10$ & 12 & 15.2 \\
\hline $\mid 10<20$ & 39 & 49.4 \\
\hline $20+$ & 25 & 31.6 \\
\hline Mean \pm SD & \multicolumn{2}{|c|}{$16.49 \pm 6.38$} \\
\hline \multicolumn{3}{|c|}{ The existence of ethical committee in the hospital } \\
\hline Yes & 3 & 3.8 \\
\hline No & 76 & 96.2 \\
\hline \multicolumn{3}{|c|}{\begin{tabular}{|l|} 
The existence of legal committee in the hospital \\
\end{tabular}} \\
\hline Yes & \multicolumn{2}{|c|}{8.9} \\
\hline No & \multicolumn{2}{|c|}{91.1} \\
\hline
\end{tabular}




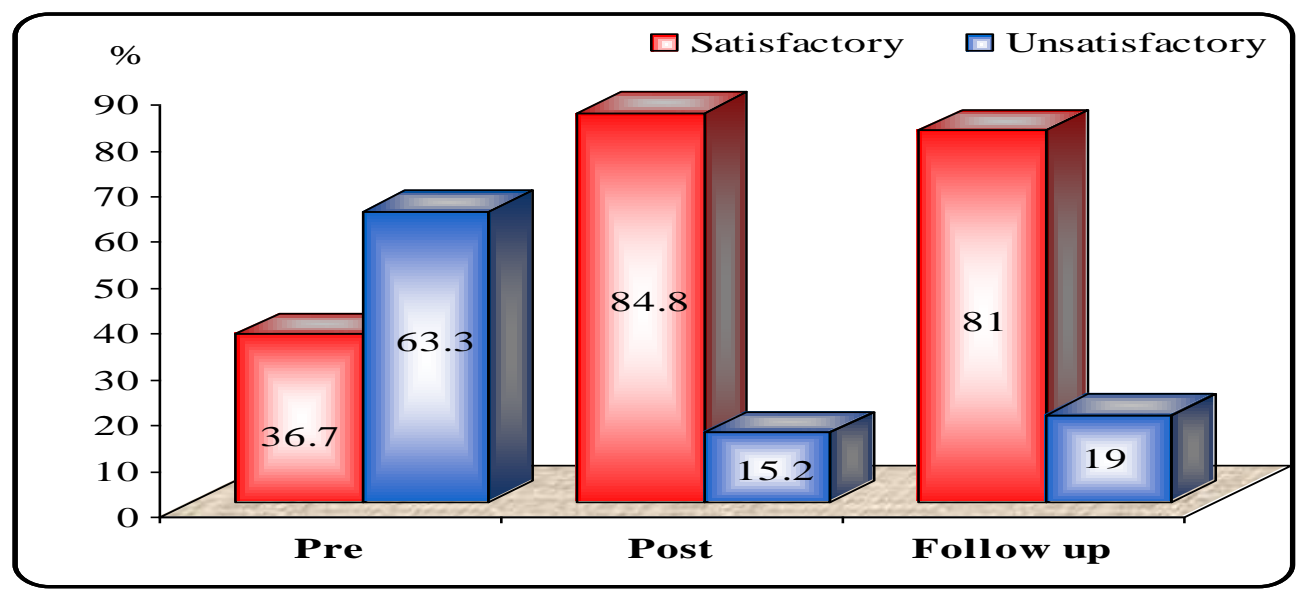

Figure (1): Nurse managers' total knowledge level about legal and ethical aspects pre, post and follow up implementation of program.

Table (2): Nurse managers' total knowledge level about legal aspects pre, post, and follow up implementation of program. $(\mathrm{No}=79)$

\begin{tabular}{|c|c|c|c|c|c|c|c|c|c|c|}
\hline \multirow{2}{*}{$\begin{array}{c}\text { Legal } \\
\text { knowledge }\end{array}$} & \multicolumn{2}{|c|}{ Pre } & \multicolumn{2}{|c|}{ Post } & \multicolumn{2}{|c|}{$\begin{array}{c}\text { Follow } \\
\text { up }\end{array}$} & \multicolumn{2}{|c|}{$\begin{array}{l}\text { Pre \&post } \\
\text { program }\end{array}$} & \multicolumn{2}{|c|}{$\begin{array}{c}\text { Post \& follow } \\
\text { up program }\end{array}$} \\
\hline & No & $\%$ & No & $\%$ & No & $\%$ & $X^{2}$ & P-value & $\mathbf{X}^{2}$ & P-value \\
\hline Satisfactory & 24 & 30.4 & 68 & 86.1 & 66 & 83.5 & \multirow{2}{*}{50.37} & \multirow{2}{*}{$<0.001 * *$} & \multirow{2}{*}{0.19} & \multirow{2}{*}{0.65} \\
\hline Unsatisfactory & 55 & 69.7 & 11 & 13.9 & 13 & 16.4 & & & & \\
\hline
\end{tabular}

** Highly statistically significant at $\mathbf{P}<0.01$

(Non-significant or $>0.05$ )

Table (3): Nurse managers' total knowledge level about ethical aspects pre, post, and follow up implementation of program. $(\mathrm{No}=79)$

\begin{tabular}{|c|c|c|c|c|c|c|c|c|c|c|}
\hline \multirow{2}{*}{$\begin{array}{c}\text { Ethical } \\
\text { knowledge }\end{array}$} & \multicolumn{2}{|c|}{ Pre } & \multicolumn{2}{|c|}{ Post } & \multicolumn{2}{|c|}{$\begin{array}{c}\text { Follow } \\
\text { up }\end{array}$} & \multicolumn{2}{|c|}{$\begin{array}{c}\text { Pre \&post } \\
\text { Program }\end{array}$} & \multicolumn{2}{|c|}{$\begin{array}{c}\text { Post \& follow } \\
\text { up program }\end{array}$} \\
\hline & No & $\%$ & No & $\%$ & No & $\%$ & $\mathbf{X}^{2}$ & P-value & $X^{2}$ & P-value \\
\hline Satisfactory & 35 & 44.3 & 67 & 84.8 & 64 & 81.0 & \multirow{2}{*}{28.32} & \multirow{2}{*}{$<0.001 * *$} & \multirow{2}{*}{0.40} & \multirow{2}{*}{0.52} \\
\hline Unsatisfactory & 44 & 55.7 & 12 & 15.2 & 15 & 19 & & & & \\
\hline
\end{tabular}

** Highly statistically significant $\quad$ (Non-significant or $>0.05$ ) 
Table (4): Nurse managers' knowledge level about legal and ethical aspects pre, post, and follow up implementation of program. $(\mathrm{No}=79)$

\begin{tabular}{|c|c|c|c|c|c|c|c|c|c|c|}
\hline \multirow{2}{*}{\multicolumn{2}{|c|}{ Items }} & \multirow{2}{*}{\multicolumn{2}{|c|}{ Pre }} & \multirow{2}{*}{\multicolumn{2}{|c|}{ Post }} & \multirow{2}{*}{\multicolumn{2}{|c|}{ Follow up }} & \multirow[t]{2}{*}{ Test } & \multirow{2}{*}{\multicolumn{2}{|c|}{ Chi-square }} \\
\hline & & & & & & & & & & \\
\hline \multirow{3}{*}{$\begin{array}{l}\text { Entrance } \\
\text { of law }\end{array}$} & Correct & 24 & 30.4 & 68 & 86.1 & 66 & 83.5 & 1 & 51.939 & $<0.001 * *$ \\
\hline & Incorrect & 36 & 45.6 & 10 & 12.7 & 11 & 13.9 & 2 & 0.411 & 0.814 \\
\hline & $\begin{array}{l}\text { Don't } \\
\text { know }\end{array}$ & 19 & 24.1 & 1 & 1.3 & 2 & 2.5 & & & \\
\hline \multirow{3}{*}{$\begin{array}{l}\text { Civil } \\
\text { cervices } \\
\text { law }\end{array}$} & Correct & 30 & 38 & 68 & 86.1 & 65 & 82.3 & 1 & 38.806 & $<0.001 * *$ \\
\hline & Incorrect & 35 & 44.3 & 8 & 10.1 & 10 & 12.7 & 2 & 0.433 & 0.805 \\
\hline & $\begin{array}{l}\text { Don't } \\
\text { know }\end{array}$ & 14 & 17.7 & 3 & 3.8 & 4 & 5.1 & & & \\
\hline \multirow{3}{*}{$\begin{array}{l}\text { Code of } \\
\text { ethics }\end{array}$} & Correct & 32 & 40.5 & 68 & 86.1 & 64 & 81 & 1 & 35.367 & $<0.001 * *$ \\
\hline & Incorrect & 44 & 55.7 & 10 & 12.7 & 13 & 16.5 & 2 & 0.846 & 0.655 \\
\hline & $\begin{array}{l}\text { Don't } \\
\text { know }\end{array}$ & 3 & 3.8 & 1 & 1.3 & 2 & 2.5 & & & \\
\hline \multirow{3}{*}{$\begin{array}{l}\text { Ethical } \\
\text { principle } \\
\text { and } P t \text {. } \\
\text { right }\end{array}$} & Correct & 38 & 48.1 & 67 & 84.8 & 64 & 81 & 1 & 24.086 & $<0.001 * *$ \\
\hline & Incorrect & 40 & 50.6 & 12 & 15.2 & 14 & 17.7 & 2 & 1.223 & 0.543 \\
\hline & $\begin{array}{l}\text { Don't } \\
\text { know }\end{array}$ & 1 & 1.3 & 0 & 0 & 1 & 1.3 & & & \\
\hline \multirow{3}{*}{$\begin{array}{l}\text { Ethical } \\
\text { dilemma }\end{array}$} & Correct & 34 & 43 & 67 & 84.8 & 64 & 81 & 1 & 29.890 & $<0.001 * *$ \\
\hline & Incorrect & 41 & 51.9 & 11 & 13.9 & 13 & 16.5 & 2 & 0.569 & 0.753 \\
\hline & $\begin{array}{l}\text { Don't } \\
\text { know }\end{array}$ & 4 & 5.1 & 1 & 1.3 & 2 & 2.5 & & & \\
\hline
\end{tabular}

Test (1) between pre and post program

** Highly statistically significant

Test (2): between post and follow up the program

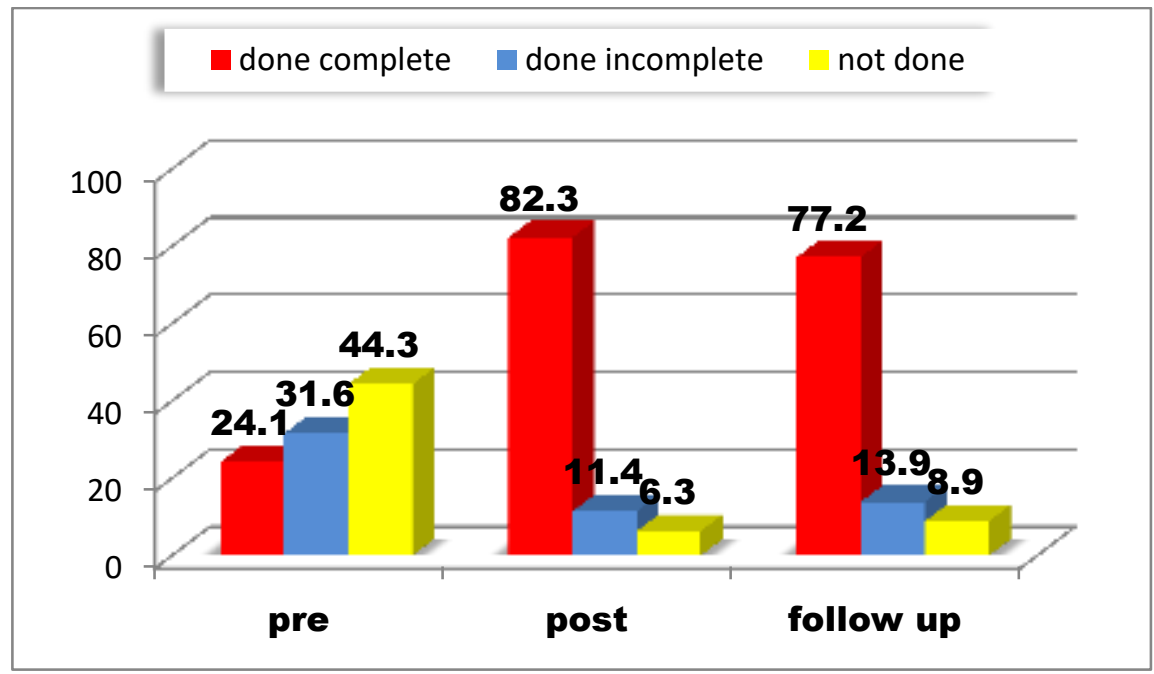

Figure (2): Nurse managers' total performance level about legal and ethical aspects pre, post and follow up implementation of program. 
Table (5): Nurse managers' performance in legal aspects pre, post, and follow up implamentation of the program $(n=79)$

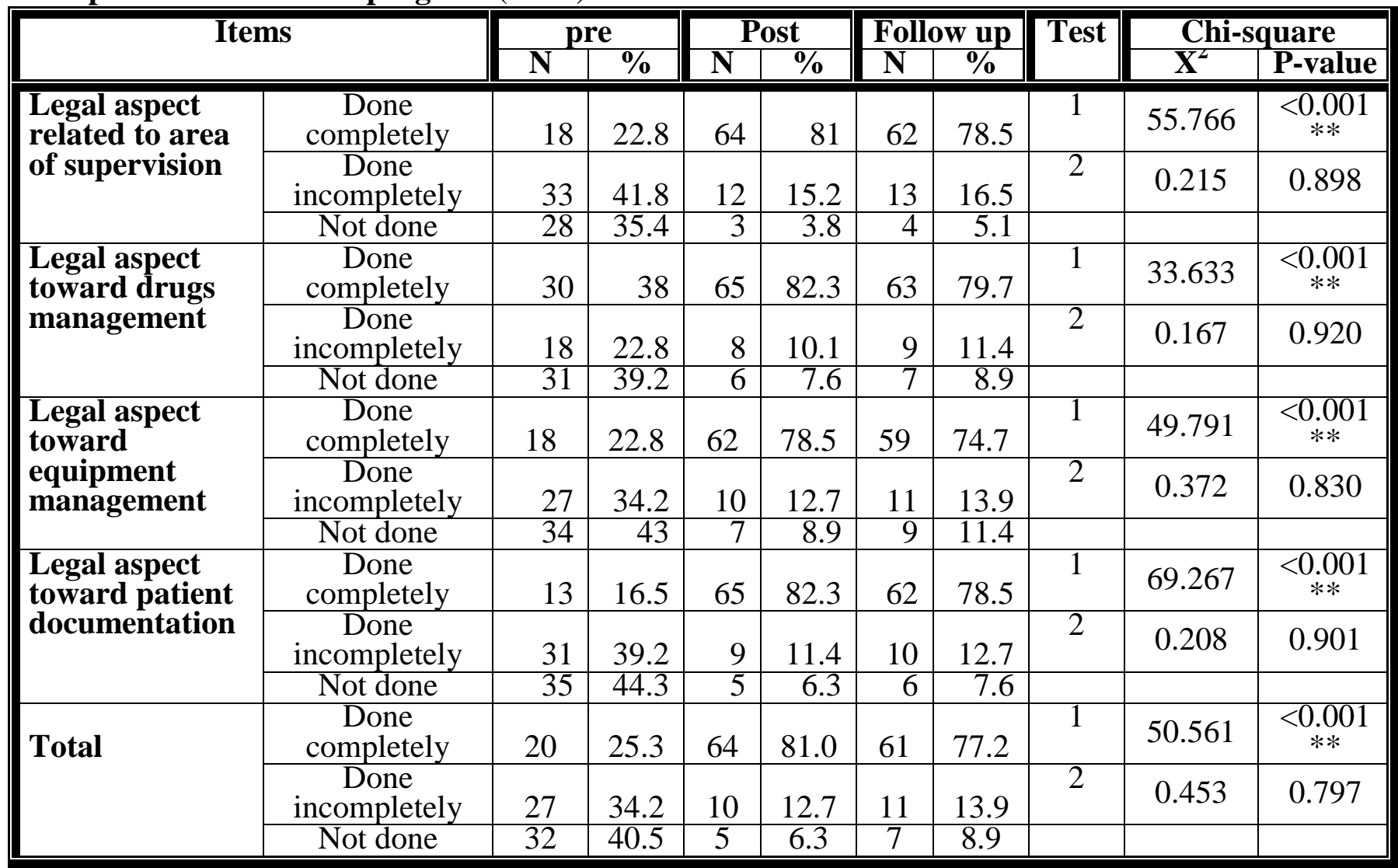

Test (1) between pre and post program

Test (2): between post and follow up the program

Table (6): Nurse managers' performance in ethical aspects pre, post, and follow up implamentation of the program $(\mathrm{No}=79)$

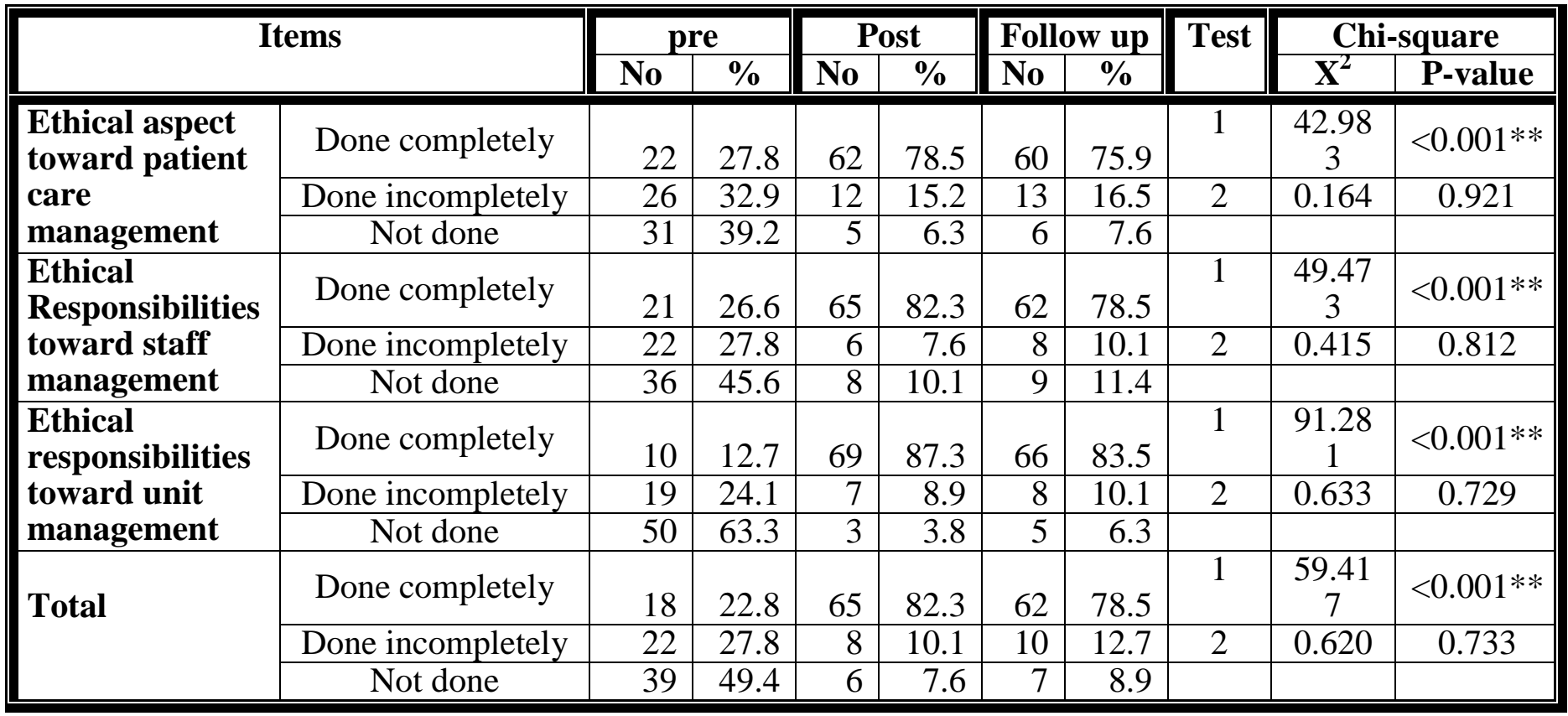

Test (1) between pre and post program

** Highly statistically significant

Test (2): between post and follow up the program 


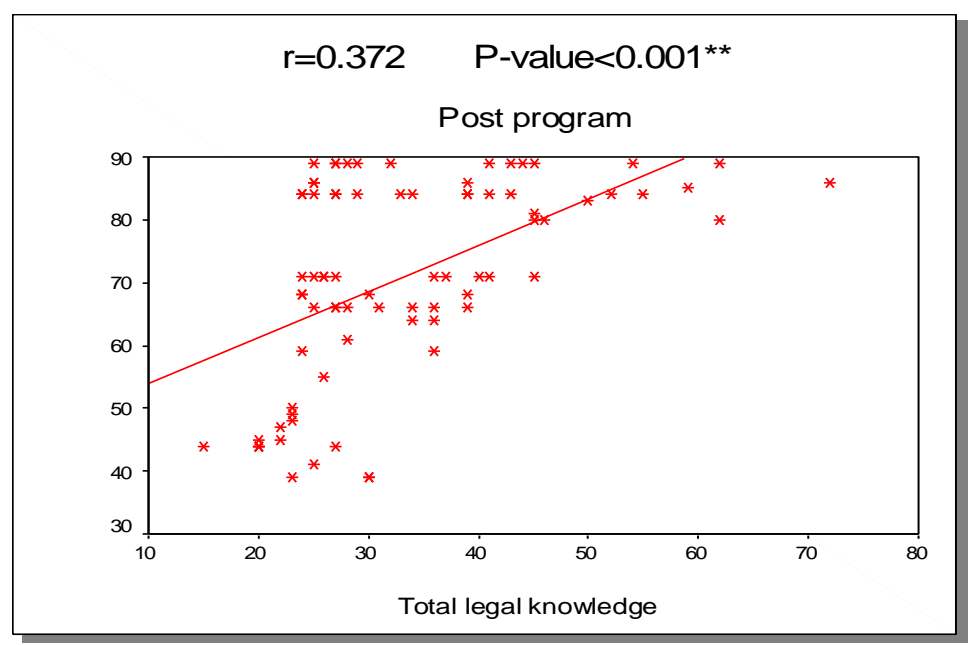

Figure (3) Correlation between nurse managers' total legal knowledge score and nurse managers' total legal performance score post implementation of program.

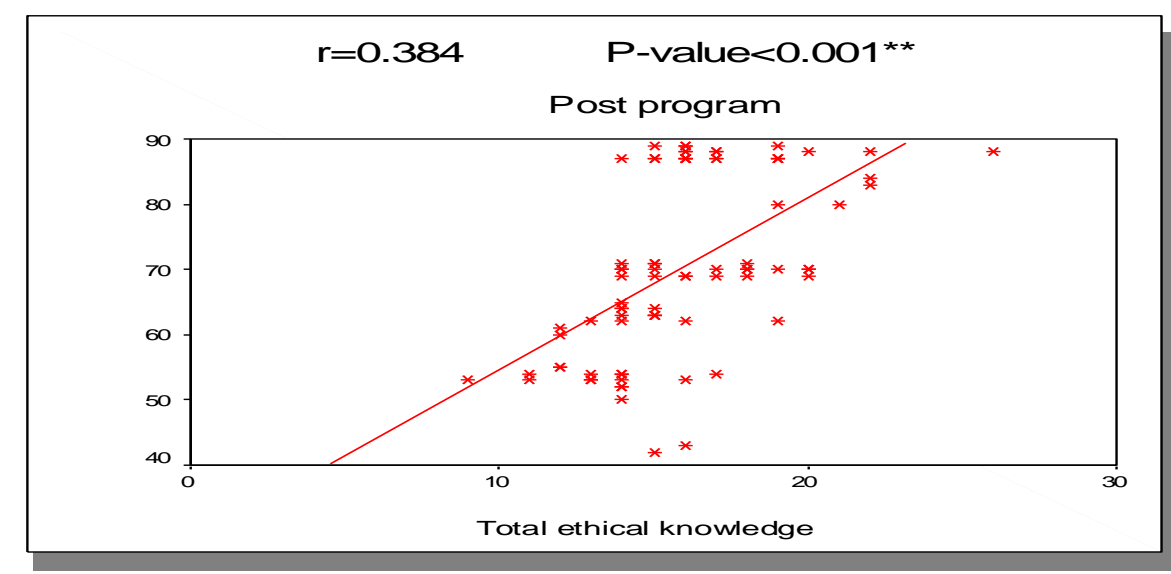

Figure (4) Correlation between nurse managers' total ethical knowledge score and nurse managers' total ethical performance score post implementation of program.

\section{Discussion}

Regarding the gender of nurse managers the present study showed that all of nurse managers were females. This finding was in agreement with Araby (2018), who found that all of nursing management staff at Benha university Hospital were females. While the Finding of present study disagreed with (Dehaghi et al., 2015), who revealed that two thirds of nurse managers at Social Security Organization in Tehran, Iran were females and one third were male. From the researcher's point of view this finding may be due to the highest ratio of female representation in healthcare sector in Egypt. From the date of the establishment of the first higher institute of nursing at Alexandria University in 1954 the nursing study was for females. In the future, the number of females will change compared to the number of males in the healthcare due to the high recruitment percentage of males to faculties of nursing all over Egypt compared to females.

As regards to age and level of education, the present study showed that less than half of the nurse managers' age were more than 45 years 
old and most of them had Bachelor Degree. These findings were supported by (Saleh et al., 2018), who found the same results with present study in their study about the impact of nurse managers' leadership styles on ward staff in Saudia Arabia. While these findings were inconsistent with (Aung \& Jamel, 2017), who found that the majority of the nurse managers at Tengku Ampuan Afzan Hospital were having A Diploma (secondry school of nursing) at their level of education. From the researcher's point of view the promotion to nurse mangers' in Egypt requires long period of work experience. Also in Egypt all levels of nursing education are available and the number of graduates from the faculty of nursing had become more than graduates from health technical institute especially after turning secondary schools of nursing into health technical institutes.

Concerning to years of experience of nurse managers, the present study indicated that less than half of nurse managers had ten to less than twenty years of work experince. This finding was supported by (Warshawsky \& Havens, 2015), who found that less than fifty percentages of nurse managers in United States of America were had more than ten years' of experience. While this finding disagreed with (Baddar et al., 2016), who found that the majority of nurse managers had one to five years' of experience in the same position in the working place at King Khalid university hospitals and Saud Medical City in Saudi Hospitals. From the researcher's point of view this may be due to higher position like nurse managers need long period of time in work setting to reach the nurse mangers position.

The present study illustrated that more than two thirds of the nurse managers had unsatisfactory total knowledge level about legal aspects before implementing the educational program, while post and follow up the educational program the majority had satisfactory total knowledge level. This finding was supported by (Ibrahim et al., 2019), who reported that the majority of nurses had poor to fair levels of knowledge about legal aspects. The study was about nurses' knowledge of legal liability in the clinical nursing practice at four hospitals affiliated to the Alexandria University. While the current study results incompatible with (Kumar et al., 2011) who reported that knowledge of nursing staff on various legal aspects were highest among those who have more than ten years of experience. The study was about knowledge of staff nurses regarding legal and ethical responsibilities in the field of psychiatric nursing at psychiatric center of Jaipur in Rajasthan. From the researcher's point of view, the improvement in the total level of knowledge and skills of nurse managers about legal aspects is due to the innovative teaching methods that have been used in the educational program. This has encouraged them to improve their knowledge and performance and helps to retain them too.

As regards nurse managers' knowledge about ethical aspects pre and post implementation of the program. The finding of present study clarifies that more than half of the study sample had unsatisfactory total knowledge level about ethical aspects in preprogram, while in the immediate post implementation of the program the majority had satisfactory knowledge level and slightly decreased in the follow-up program. This finding was supported by (Maharjan et al., 2019), who illistarate that around half of the nurses had adequate knowledge level of ethical aspects, and they emphasize on the need for making aware about legal aspects. The study was about awareness of nurses on 
legal and ethical aspects of nursing in Hospitals of Lalitpur in Nepal.

This result was inconsistent with (Aliyu et al., 2015), who stated that the majority of the participants possess good knowledge of ethical dilemma. The majority of the participants had previous knowledge about ethical dilemma mostly through seminars/workshops followed by those who know from respective schools training. The study was about knowledge, attitude and practice of nursing ethics and law among nurses at Federal Medical Centre in Bida.

From the researcher's point of view, ethics plays significant role with nurse managers' responsibilities. Ethical problems are part of daily management process. The nurse manager should be honest and act with integrity and take responsibility for her own learning, proficiency and development herself beside in-service training program. Additionally the slightly decreased in knowledge level in the follow-up phase as compared to immediate post program but still more than preprogram this may be due to the knowledge is decrease with time and nurse managers need to periodic refreshing and updating of knowledge through continouning education.

The findings of the current study revealed that two thirds of the study sample had unsatisfactory knowledge level about legal and ethical aspects in preprogram, while immediate post and follow up educational program the majority had satisfactory knowledge level.

The current study disagreed with (Hafez et al., 2016), who concluded that more than half of nurses at Mansoura University Hospital had a satisfactory knowledge about ethical aspects, and most of them had adequate professional practice regarding the ethics, their practice of professional ethics is much better than their knowledge. From the researcher's point of view, an educational program was beneficial to nurse managers' legal and ethical knowledge, and they gain good knowledge. After three months knowledge become little less but still high compared to pre-program that's why we need continuous educational program.

The current study showed that total level of nurse managers' performance in preimplementation of the program that the minority of nurse managers done incomplete performance toward legal and ethical aspects. While in post program the majority of them done complete legal and ethical performance. These findings were supported by (Devi, 2017), who reported that nurses were lacking knowledge on legal responsibility in nursing which is one of the vital aspects of nursing practice and there is need to improve knowledge of the nurses on legal responsibility. The study was about nurse's awareness on legal and ethical responsibilities in nursing at Manipal Teaching Hospital in Nepal.

The study findings were incongruent with (Kumar et al., 2011), who reported that a majority of the respondents categorically denied having received any structured or unstructured training about legal aspect during their basic training through their employers and most of their study sample having legal knowledge. Lack of time, ignorance and lack of information technology skills were main reasons for not keeping themselves abreast with legal updates. From the researcher's points of view to work effectively with high quality you need enough knowledge. Knowledge helps nurse managers to feel satisfied and self-confidence during 
their daily activity etheir with routine work or in emergency situation.

The present study showed that there were highly statistically significant positive correlation among nurse managers' legal and ethical total knowledge scores and nurse managers' legal and ethical total performance scores after implementation of the program. These findings were consistent with (Safa \& Hajbagheri, 2019), who showed that there were a significant relationship between score of nurses' awareness of legal aspect related to caring for older adults and their previous training. The study was about how is nurses' awareness of ethical and legal Issues related to caring for older Adults. Additionaly this results were supported by (Zakaria et al., 2016), who revealed that there was high significance relation between knowledge of nursing ethics and ethical behavior after the in-service training program. The study was about effectiveness of ethical issues teaching program on knowledge at Mansoura emergency hospital.

From the researcher's point of view the nurse managers' responsibility is to create good working environment with high quality of care. Also, to work effectively with high quality nurse managers need enough knowledge. Knowledge helps them to feel satisfied and self-confidence during their daily activity. Good performance based on amount of knowledge can be used in clinical practice, stress, decision-making and emergency situation.

\section{Conclusion:}

There was an improvement in nurse managers' level of knowledge and performance about legal and ethical aspects immediately post implementation of the educational program and in follow-up compared to pre-program. There was high statistical significant difference between nurse managers knowledge and performance about legal and ethical aspects pre and immediate post implementation of the educational program. While there was no-statistical significant difference between nurse mangers knowledge and performance about legal and ethical aspects immediate post and follow up implementation of the educational program.

\section{Recommendations:}

I- Establish an ethical and legal committee within the organization for all ethical and ethical aspects in nursing practice.

2-Assess periodically the training needs of the nurse managers' to nursing legal and ethical aspects.

3-Design implement and evaluate training program based on nurse managers training needs.

4- Establish laws regarding types of medical and nursing torts (mal-practice or negligance) of all kinds with determine penalties for each medical or nursing error. 


\section{Referances}

Abo-Roman, N. Z. H. (2019). Medical Responsibilities for the Action of Others, Doctorate unpublished thesis, Faculty of Law, Cairo University, Pp 33-34

Aliyu, D. \& Adeleke, I. T. \& Omoniyi, S. O. \& Samaila, B. A. \& Adamu, A. \&

Abubakar, A. Y. (2015). Knowledge, attitude and practice of nursing ethics and law among nurses at Federal Medical Centre, Bida, American Journal of Health Research, 3(1), Pp. 32-37 https://pdfs.semanticscholar.org/ffe9/94f32bb e1d549015df3b42230d79616c62ef.pdf

Alrobai, T. (2020). The Impact of Nurse Leaders/Managers Leadership Style on Job Satisfaction and Burnout among Qualified Nurses: A Systematic Review, Journal of Nursing and Health Science, 9(1), Pp.18-19, retrieved from http://www.iosrjournals.org/iosrjnhs/papers/vol9-issue1/Series8/C0901081741.pdf

Al-Breiki, M. (2017). What Influence Nurses Practice More; Law or Ethics, Nursing and Health Care Journal, 5 (3), Pp.1-3 retrieved from https://juniperpublishers.com/jojnhc/pdf/J OJNHC.MS.ID.555664.pdf

American Nurse Association (ANA), (2019). Ethics and Human Rights, Code of Ethics for Nurses, retrieved from https://www.nursingworld.org/practicepolicy/nursing-excellence/ethics/

Araby S. M. (2018). Enhancing Creativity and Change of Nursing Management Staff and its Influence on their Performance, Doctorate unpublished thesis, Faculty of Nursing, Benha University.
Ashour, S., (2006). Civil Law, Responsibility for the work of others, Implementation by Compensation, chap 2, Pp. 55-69:72 Nass Printing Company, Cairo, Egypt

Aung, K. T, \& Jamel, Q. A, (2017). Nurse managers' perspectives on Nurses' Performance in Mentorship Program, international Islamic university, 27 (1), Pp.139-143, retrieved fromhttps:// www .researchgate .net/publication /321095792 _Nurse _managers '_perspectives_on _nurses'_performance_in_mentorship_pro gram

Baddar, F. \& Salem, O., A \& Hakmi, A. (2016). Nurse Manager's ethical attitudes and Preparedness towards effective delegation in Saudi Hospitals, Health Science Journal, 10 (3), retrieved from http://www.hsj.gr/medicine/nursemanagers-attitudes-and-preparednesstowards-effective-delegation-in-saudihospitals.pdf

Dagogo, M. \& Ehior, I. E. (2019). Diversity and Ethical Issues in the Organizations, International Journal of Academic Research in Social Science, 9 (2), Pp. 841:842 retrieved from https://hrmars.com/papers_submitted/562 0/Diversity_and_Ethical_Issues_in_the_O rganizations.pdf

Daly, J. \& Jackson, D. \& Mannix, J. \& Davidson, P. M. (2014). The Importance of Clinical Leadership in the Hospital Setting, Journal of healthcare leadership, 6 (1), Pp. 75-67, retrieved from, https://www.researchgate.net/publication/ 287541104_The_importance_of_clinical_ leadership_in_the_hospital_setting

Dehaghi, Z. \& Sheiktaheri, A. \& Dehnavi, F. (2015). Nurse Managers' Work Life Quality and Their Participation in Knowledge Management, at Social 
Organization in Tehran, Iran Red Crescent medical journal, 17(1), Pp.98:101, retrieved from https://www.ncbi.nlm.nih. pmc/articles/PMC4341403

Demirhan, B. S. \& Gezginci, E. \& Goktas, S. (2020). The Effect of Leadership Behaviors of Nurse Managers on Nurses' Work Motivation, International Journal of Caring Sciences, 13(1), Pp. 381-382, retrieved

from http://www.internaionaljournalofcaringsci ences.org/docs/43_gezgincielif_original_ 13_1.pdf

Devi A., (2017). Nurse's Awareness on Legal and Ethical Responsibilities in Nursing, International Journal of Nursing Research and Practice, 4 (1), Pp. 53:55.

Donates, G. (2011). Ethical Issues in Health Care in Kenya, Critical Analysis of Healthcare Stakeholders, Journal of Finance and Accounting, 2(3), P. 123, retrieved from https://core.ac.uk/download/pdf/2346291 94.pdf

Drucker, P. (2018). Day-to-Day Operations; Nurse Manager Survival Guide, $4^{\mathrm{TH}}$ edition, chap. 4, Pp.101-104:105, retrieved from https://sigma.nursingrepository.org/bitstre am/handle/10755/623550/FreeDownload_ NurseManagersSurvival\%20Guide4thEdit ion_Marrelli.pdf?sequence $=1 \&$ isAllowed

El-Bayome, A. M. (2017). Assessment of Knowledge and Practice Regarding Legal and Ethical Aspects of Nursing Practice among Nurses at surgical Zagazig University Hospital, master unpublished thesis, Pp. 29-30

Feather, R. \& Ebright, P. R. (2013). How Staff RNs Perceive Nurse Manager Roles, journal of leadership, 2(3), P. 68, retrieved

from https://www.researchgate.net/publication/ 269792853_How_Staff_RNs_Perceive_N urse_Manager_Roles

Fukada, M. (2018). Nursing Competency; Definitions Structure and Development, Journal of Medical Science, 6(1), Pp.1-2, retrieved

from https://www.ncbi.nlm.nih.gov/pmc/article s/PMC5871720/

Gab-Allah, R. \& Elshrief, E. \& Ageiz, M. H. (2020). Developing Strategy: A guide For Nurse Managers to Manage Nursing Staff Work-Related Problems. Asian Nursing Research, 14(3), Pp. 1-2 retrieved from https://www.researchgate.net/publication/ 343044810_Developin

g_Strategy_A_guide_For_Nurse_Manage rs_to_Manage_Nursing_Staff_WorkRelated_Problems

Habimana, A. (2016).Clinical Supervision of Nursing Students: Challenges and Alternatives, College of Medicine and Health Sciences, Rwanda Journal, 3(1), retrieved from www.file:///C:/Users/3com /Downloads/147020-388160-1-SM.pdf

Haddad, L. M. \& Geiger, R. (2020). Nursing Ethical Considerations, Code of Ethics, retrieved from https://www.ncbi .nlm.nih .gov/books/NBK526054/

Hafez, F. E. \& Mohamed, H. A. \& Sobeh, D. E., (2019). Assessment of Nurses' Knowledge and Practice Regarding Professional Ethics in Outpatient Clinics at Mansoura University Hospital, Journal of Nursing and Health Science, 5 (6), Pp. 20-26, retrieved from http://iosrjournals.org/iosrjnhs/papers/vol5-issue6/Version7/C0506072028.pdf 
Hamid, S. (2016). Ethical Issues Faced by Nurses During Nursing Practice in District Layyah, Pakisttan, Diversity and Equality in Health and Care, 13 (4), https://diversityhealthcare.imedpub.com/e thical-issues-faced-by-nurses-duringnursingpractice-in-district-layyahpakistan.php?aid=10616

Hariharant, S., (2013). Knowledge, Attitudes, and Practice of health care Ethics and Law among Doctors and Nurses in Barbados, accessed in febrory 2016 from http://bmcmedethics.biomedcentral.com/p df

Ibrahim, A. E. \& Hussein, A. \& Hussien, R. (2019). Nurses' Knowledge of Legal Liability in the Clinical Nursing practice, at four hospitals affiliated to the Alexandria University, Journal of Nursing and Health Science, 8 (6), Pp.72-57, retrieved from https://pdfs.semanticscholar.org/9852/817 b6ddcf3a765452ba5886d24e10872dd54.p df?_ga=2.250139270.1637524963.15977 79713-224939991.1596783716

Joseph S., (2017): Nursing Administration and Management; Legal and Ethical Issues, unit 29, Pp. 478-479, Aitbs Publishers, India

Karaca A. \& Durna, Z. (2019): Patient Satisfaction with the Quality of Nursing Care, journal of nursing open, 6(2), Pp.534-535, retrieved from https://www.ncbi.nlm.nih.gov/pmc/article s/PMC6419107/

Kumar, R. \& Mehta, S. \& Kalra, R. (2011): Knowledge of Staff Nurses Regarding Legal and Ethical Responsibilities in the field of Psychiatric Nursing, Nursing and Midwifery Research Journal, 7 (1), Pp.12 , https://www.researchgate.net/publication/ 331062963_Knowledge_of_staff_nurses_ regarding_legal_and_ethical_responsibilit ies_in_the_field_of_psychiatric_nursing

Lundy, K. S. \& Janes, S. (2016): Community Health Nursing, Caring for the Public Health, politics and the law, chap 9, P 241, Jones and Bartlett learning company, United states of America

Maharjan S. \& Thapa M. \& Maharjan B. (2019): Awareness of Nurses on Legal and Ethical Aspects of Nursing, in Selected Hospitals of Lalitpur, International Journal of Health System and Implementation Research, 3 (2), Pp.25-27-28, file:///C:/Users/3com/Downloads/40Article\%20Text-341-1-10-20191204.pdf

Mahran, S. M. (2017). Nurse's Perception of Practice Environment and Its Relation to Quality of Patient Care in Port Said Selected Governmental Hospitals, Zagazig Nursing Journal, 13(1), Pp.70-71, retrieved from https://znj.journals.ekb.eg/article_38263_ 3 efd $43 d$ 386e5c387b4325b9bdaeb9029.pdf

Mohamed, A. M. (2017). Assessment of Knowledge and Practice Regarding Legal and Ethical Aspect of Nursing Practice, Master unpublished thesis, Faculty of Nursing, Zagazig University.

Molina-Mula, M. \& Estrada, J. G. (2020). Impact of Nurse-Patient Relationship on Quality of Care and Patient Autonomy in Decision-Making, International Journal of Environment Research and Public Health, 2(1), Pp.2-3, retrieved from file:///C:/Users/3com/Downloads/ijerph17-00835-v2\%20(1).pdf 
Ragon, C. (2016). Elements and Strategies for Ethical Decision- Making in Nursing, International Journal of Healthcare Sciences, 25 (2), Pp. 101- 103, retrieved from http://www. scielo.br /scielo.php? script =sci_arttext\&pid=S010407072016000200503

Safa, A. \& Hajbagheri, A. (2019). How is Nurses' Awareness of Ethical and Legal Issues Related to Caring for Older Adults, International Journal of Ethics \& Society, 1 (3), Pp.1-4, retrieved from http://ijethics.com/article-1-50-en.pdf

Salah, U. \& Alsubhi, H. \& Connort, T. \& Alkattan, P. (2018). The Impact of Nurse Managers' Leadership Styles on Ward Staff, British Journal of Nursing, 27 (4), Pp.198-199, retrieved from https://www.researchgate.net/publication/ 323343723_The_impact_of_nurse_manag ers\%27_leadership_styles_on_ward_staff

Shrestha, S. (2014). Knowledge and Practice of Nursing Ethics and Laws Journal of Universal College of Medical Sciences, 2 (3), Pp.31:33, retrieved from file://C:/Users/3com/Downloads/11825-

Article\%20 Text -41448-1-1020141231\%20(1).pdf

Singh, A \& Mathuray, M. (2018). Are Nurses Adequately Informed About the Law and Their Legal Responsibilities when Administering Health Care, Journal of Nursing Profession in South Africa, 5(1), Pp. 123-124, retrieved from https://www.researchgate.net/publication/ 327112951_The_nursing_profession_in_ South_Africa_-

_Are_nurses_adequately_informed_about _the_law_and_their_legal_responsibilities _when_administering_health_care

Vati, J. (2014). Nursing Management and Administration; Legal Foundation of
Nursing Practice, chap. 5, Pp. 64-66, Jaypee Brother Medical Publishers, New Delhi

Warshawsky N. E., \& Havens D. S., (2015). Nurse Manager Job Satisfaction and Intent to Leave, 32 https://www.ncbi.nlm.nih.gov/pmc/article s/PMC4330008/

Weberg, D. \& Mangold, K. \& Porter, T. \& Malloch, k. (2019). Leadership in Nursing Practice; Principle of Ethical Decision Making, Chap. 6, Pp. 211:112, Jones \& Bartlet Company, United State of America,

Wise, Y. (2015). Leading and Managing; Legal Issues, chap2, 6 edition, Pp. 96-97, elsevier.com, Chine

World Health Organization (WHO), (2019). Code of Ethics and Professional Conduct, ethical principle, P. 10, retrieved from https://www.who.int/about/ethics/code_of _ethics_full_version.pdf

Younis, S. (2017). Assessment of Problem Solving Skills and Factor Influencing Decision Making among Nursing Management Staff, Master Unpublished thesis, Faculty of Nursing, Benha University.

Zakaria, A. \& Seada A. M. \& Sleem, W. (2016). Effectiveness of Ethical Issues Teaching Program on Knowledge, Ethical Behavior and Ethical Stress Among Nurses, Journal of Nursing Education and Practice, 6 (7), Pp.125-128, retrieved from https://www.researchgate .net/publication/299422414_Effectiveness _of_ethical_issues_teaching_program_on _knowledge_ethical_behavior_and_ethica 1_stress_among_nurses 


\section{تعزيز الجوانب القاتونية والأخلاقية لمديرى التمريض بمستشفي بنها الجامعي \\ سلوى محمود محمد مصطفى- ايمان سالمان طايع - هويدا حسن السيد مجفوظ}

مديري التمريض هم العقل المدبر و المسئول عن الفريق التمريضي فى النظام الصحي، فهم مسؤولون عن تتظيم الوحدات و الأقسام داخل المستشفى وهمزة وصل بين مقدمي الرعاية الصحية أطباء ،ومرضى واسر المرضى ، تبدأ مسؤولياتهم بتوزيع العمل ، وتمتد إلى جودة الخدمة المقدمة وضمان تطبيق الأسس والقواعد و اللوائح المعمول بها داخل المستشفى ، مع كل هذا يجب أن تحرص على تطبق القيم والعادات و الجوانب الأخلاقية. أجريت الدراسة الحالية في جميع الأقسام و الوحدات بمستشفى بنها الجامعي ، وييلغ اجمالي عددهم ( § ) وحدة، أسفرت النتائج عن وجود تحسن في مستوى معرفة وأداء مديري التمريض عن الجوانب القانونية والأخلاقية مباشرة بعد تنفيذ البرنامج وعقب ثلاث اثهر من التنفيذ مقارنة بما قبل البرنامج ـ كما اوصت الدر اسة: بأنشاء لجنة قانونية واخلاقية لحل المشكلات القانونية والأخلاقية بين اعضاء الفريق الطبي و المريض. 